\title{
Phytoplankton from NE Doñana marshland (“El Cangrejo Grande”, Doñana Natural Park, Spain)
}

\author{
I. Reyes ${ }^{1, *}$, G. Martín ${ }^{1}$, M. Reina ${ }^{1}$, A. Arechederra ${ }^{1}$, L. Serrano ${ }^{1}$, M.A. Casco ${ }^{2}$ and \\ J. Toja ${ }^{1}$
}

1 Dpto. Biología Vegetal y Ecología. Facultad de Biología. Universidad de Sevilla. Apdo.1095, 41080-Sevilla. España.

2 División Ficología, Facultad de Ciencias Naturales y Museo. Universidad Nacional de La Plata. Paseo del Bosque s/n. 1900. La Plata. Argentina.

* Corresponding author: irbarbara@us.es

\begin{abstract}
Phytoplankton from NE Doñana marshland ('El Cangrejo Grande”, Doñana Natural Park, Spain)

The study area ("El Cangrejo Grande", Doñana Natural Park) is located at the final section of the Guadiamar River channel and it is a part of the NE Doñana marshland. The hydrological characteristics of the area are complex and dynamic due to the different origin of its water input: the Guadiamar River basin, the Guadalquivir River estuary, and rice paddies outlets. This area is included in the hydrologic regeneration plan for the Doñana marshland ("Doñana 2005"), though the present study was finished before any modification took place. Phytoplankton richness was high since a total of 224 phytoplankton taxa were registered. Diatoms and Clorophytes were the groups that had the highest richness, Nitzschia palea, Cyclotella atomus and Monoraphidium contortum being the most widely distributed and abundant species. Phytoplankton exhibited a strong seasonal variation, in both composition and biomass, segregated in two periods (flood and desiccation) as suggested by the results of the PCA. On the other hand, the spatial differences were less evident according to a multidimensional scaling analysis (MDS). This seasonal pattern was stronger in the ordination of physico-chemical variables (conductivity, nutrient concentration and suspended matter). We conclude that this system is an ecotone zone with a high hydrologic complexity due to a variety of water inputs with a strong seasonality. These hydrologic features would be the determining factor in phytoplankton composition and high taxon richness.
\end{abstract}

Key words: Phytoplankton, Doñana, marshland, temporal segregation, wetlands.

\section{RESUMEN}

Fitoplancton del NE de las marismas de Doñana (“El cangrejo Grande”, Parque Nacional de Doñana, España)

El Lucio de "El Cangrejo Grande" (Parque Natural de Doñana) está situado en el tramo final del encauzamiento del río Guadiamar y forma parte de la marisma NE de Doñana. Las características hidrológicas de la zona son complejas y dinámicas debido a los diferentes aportes que recibe de la cuenca del Guadiamar, del estuario del Guadalquivir y del desagüe de los arrozales. Esta zona está incluida dentro del Plan de Regeneración Hídrica ("Doñana 2005") aunque el presente trabajo finalizó antes de que se llevaran a cabo las actuaciones previstas. La riqueza del fitoplancton fue elevada ya que se registró un total de 224 taxa. Las Diatomeas y las Clorofitas fueron los grupos que reunieron mayor riqueza, siendo Nitzschia palea, Cyclotella atomus y Monoraphidium contortum las especies más representativas, en abundancia y distribución. El fitoplancton presentó una fuerte variación estacional, en composición y biomasa, identificándose claramente una dinámica temporal repartida en dos períodos (inundación y estiaje) como sugieren los resultados del análisis de componentes principales. En cambio, las diferencias espaciales fueron menos evidentes como demostró el análisis de ordenación multidimensional no jerárquico $(M D S)$. El patrón estacional fue aún más marcado en el análisis de las principales variables físico-químicas (conductividad, concentración de nutrientes y materia en suspensión). Se concluye que este sistema corresponde a una zona de ecotono de gran complejidad hidrologica debido a la existencia de una variedad de aportes hídricos sujetos a variaciones estacionales; esta complejidad sería el factor determinante de la composición y elevada riqueza del fitoplancton.

Palabras clave: Fitoplancton, Doñana, marisma, segregación temporal, humedal. 


\section{INTRODUCTION}

Coastal ecosystems (tidal marsh, estuaries, deltas, lagoons, etc) are naturally very productive systems as the result of physico-chemical processes taking place in shallow water, with frequent and intense winds, and high nutrient loads (Pomeroy, 1977; Odum, 1988; Muylaert \& Raine, 1999). This kind of systems is difficult to study because they are very dynamic and subject to variable stages (Comín et al., 1999). Phytoplankton in coastal ecosystems under Mediterranean climate is largely influenced by hydrologic features, nutrient availability and seasonality (Comín \& Valiella, 1993; Gilabert, 2001; Quintana \& Moreno-Amich, 2002; Nuccio et al., 2003; Ortega-Mayagoitia et al., 2003; Hlaili et al., 2006). There are few publications on phytoplankton assemblages in this kind of systems (López, 1987; Sabater \& Muñoz, 1990; Romo \& Miracle, 1994; Gilabert, 2001; Puigserve et al., 2002; Rodrigo et al., 2003; Villena \& Romo, 2003; López-Flores et al., 2006). The present study is the first publication relating phytoplankton composition and richness to seasonality in the Doñana marshland. The study area ("El Cangrejo Grande", Doñana Natural Park) is located on the NE Doñana marshland. The hydrology of the area is complex and dynamic due to different water inputs: Guadiamar River basin, Guadalquivir River estuary and outlet of rice paddies (Serrano et al., 2006). Although most part of the Doñana inland marshland has no tidal influence, the study area is influenced by Atlantic tides from the estuary of the Guadalquivir River. Both the estuary and the eastern Doñana marshland have been impacted by eutrophication and heavy metal pollution for decades (Cabrera et al., 1984, 1987; Arambarri et al., 1984, 1996; Zurera et al., 1987; Serrano et al., 2006). In 1998, $5 \mathrm{hm}^{3}$ of mud and acid water with high concentrations of heavy metals were dumped to the Guadiamar River, from an open-cast mine in Azanalcóllar, and flooded an extension of 2600 ha downstream. An extensive cleaning activity took place in the river floodplain that was eventually protected as a buffer area ("Paisaje Protegido-Corredor Verde del Guadiamar"). Additionally, a hydrologic re- generation plan ("Doñana 2005") has been developed to recover the original water input in order to counterbalance the tendency towards desiccation and silting-up of the Doñana marshland during the past 50 years. The hydrology of the study area, in particular, is planned to be altered by three different modifications, but none of them took place before the end of 2004. Therefore, the present study on phytoplankton composition, richness, and dynamics was carried out prior to any modification.

\section{MATERIAL AND METHODS}

\section{Study area}

Doñana has a Mediterranean climate with Atlantic influence, generally classified as dry sub-humid. Rainfall is quite variable, both within a year and over the years. It has a $580 \mathrm{~mm}$ yearly average rainfall, about $80 \%$ of which is distributed throughout a wet period from the end of September to the beginning of April. Summers are very dry and hot, while winters are short and mild. Water balance is generally deficient as rainfall exceeds evapotranspiration only during 3-4 months of the year (Siljeström \& Clemente, 1990).

About 23000 ha of the Doñana marshland is protected as either a National Park or Natural Park (Fig. 1). The study site covers 250 ha of the final stretch of the Guadiamar River encroached by two parallel levees built in 1956 (Fig. 1). It includes natural and man-made waterways, isolated water-bodies, and a beachlike-floodplain locally named Lucio, which gives name to the whole site ("Lucio, El Cangrejo Grande"). Most of the Guadiamar River water flow is diverted towards the Guadalquivir River estuary through an artificial canal which is permanently connected to the study area by two inlets (Fig. 1, sites $\mathrm{B}$ and $\mathrm{C}$ ), seasonally by a floodgate (Fig. 1, site D), and occasionally during floods by the outflow of the Guadiamar River (Fig. 1, site A). Water in the study area is generally temporary and shallow except at the floodgate where water can reach up to $2 \mathrm{~m}$ during high-tide. Water temperature ranges from $8^{\circ} \mathrm{C}$ to $30^{\circ} \mathrm{C}$, conductivity (at 


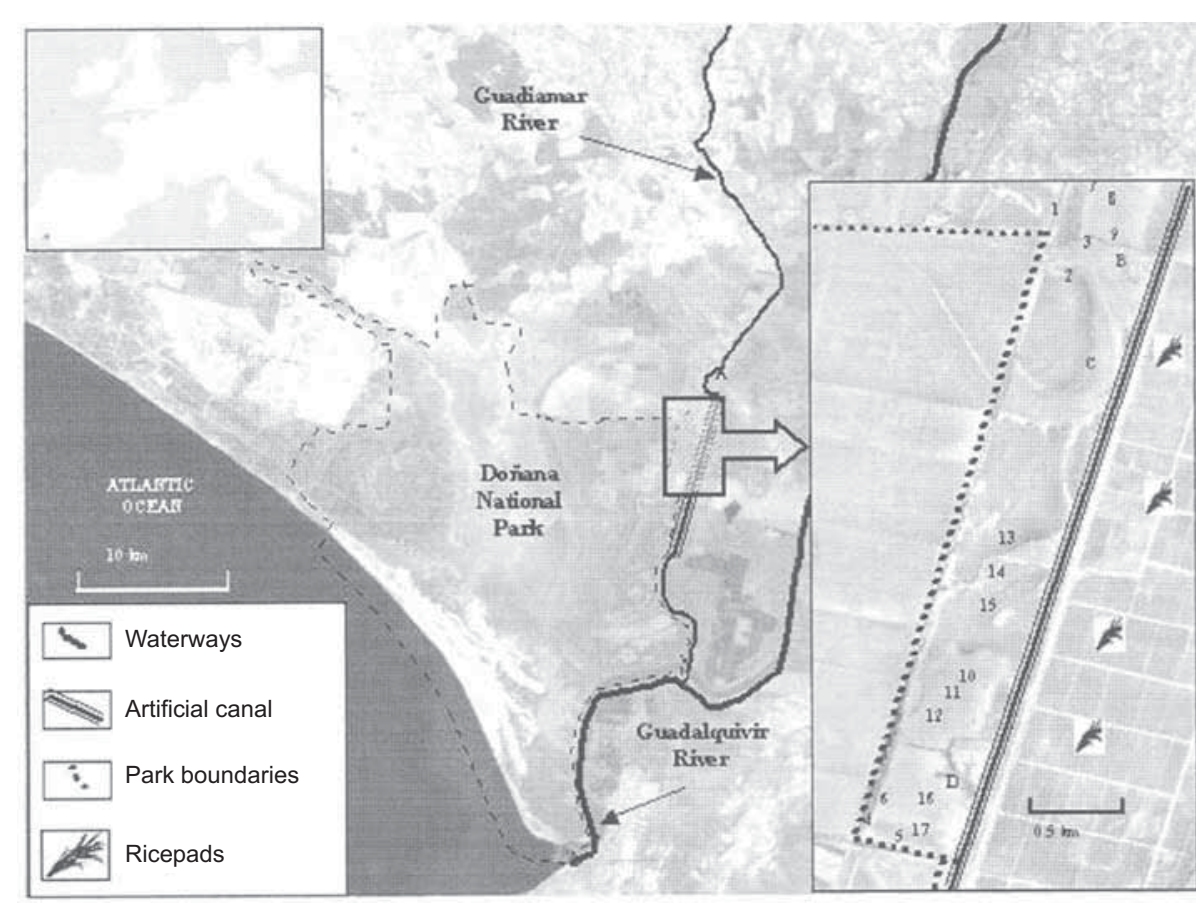

Figure 1. Location of the study site (Lucio El Cangrejo Grande) at the end of the Guadiamar River channel. Sampling stations at the inlet sites are represented by letters (A, B, C, and D) while the inner sites are numbered. Localización del área de estudio (Lucio El Cangrejo Grande) en el tramo final del encauzamiento del río Guadiamar. Se indican las estaciones de muestreo de las "entradas" mediante letras ( $A, B, C$ y $D$ ) y con números los puntos interiores.

$20^{\circ} \mathrm{C}$ ) from $0.5 \mathrm{mS} \mathrm{cm}{ }^{-1}$ to $15.7 \mathrm{mS} \mathrm{cm}{ }^{-1}, \mathrm{Na}^{+}$ is the dominant cation in the floodplains while $\mathrm{Ca}^{2+}$ dominates in some waterways. Water flowing through the artificial canal is usually turbid due to a high load of inorganic suspended matter largely composed of $\mathrm{CaCO}_{3}$ particles associated to P (Reina et al., 2006). In contrast, the southern marshland generally presents a better water quality with higher transparency and relatively lower concentrations of $\mathrm{N}$ and $\mathrm{P}$ (Espinar et al., 2002). Vegetation in elevated areas is dominated by Sarcocornia fruticosa and Hordeum marinum, while aquatic emergent macrophytes (Phragmites australis, Scirpus maritimus, Juncus subulatus) and submerged macrophytes grow in flooded areas (Chara galioides, Callitriche truncata, Ranunculus peltatus, Ruppia drepanensis).

Twenty-one sampling sites were located within the study area and were sampled eleven times from September 2002 to September 2004 (Fig. 1). Four sites corresponded to inlets, of which only three acted as outlets during floods or tidal flows (sites B, C and D). Dissolved oxygen, $\mathrm{pH}$, and electrical conductivity were measured in situ. Surface water was collected with 1.5 L PET bottles at each site for chlorophyll $a$ determination (methanol extraction following Marker et al., 1980), suspended matter (gravimetrically with previously dry filters at $100^{\circ} \mathrm{C}$ ), and nutrient concentrations in 2-4 replicates after filtration through WHATMAN GF/C filters in the laboratory: nitrite (Strickland \& Parsons, 1972), nitrate (Golterman, 1991), ammoniun (Rodier, 1981), and phosphate (Murphy \& Riley, 1962). The concentration of total $\mathrm{P}$ in the water was determined in duplicates as phosphate after acid digestion with $0.5 \mathrm{M} \mathrm{H}_{2} \mathrm{SO}_{4}$ and $0.5 \mathrm{~g} \mathrm{~K}_{2} \mathrm{~S}_{2} \mathrm{O}_{8}$ at $120^{\circ} \mathrm{C}$ for 3-4 h (De Groot \& Golterman, 1990).

Water samples of $125 \mathrm{ml}$ were preserved in situ with lugol, and the determination of phytoplankton composition and abundance was performed in duplicates. Most phytoplankton taxa were identified to species with an optical microscope (magnification: 400x and 1000x). Abundance of 


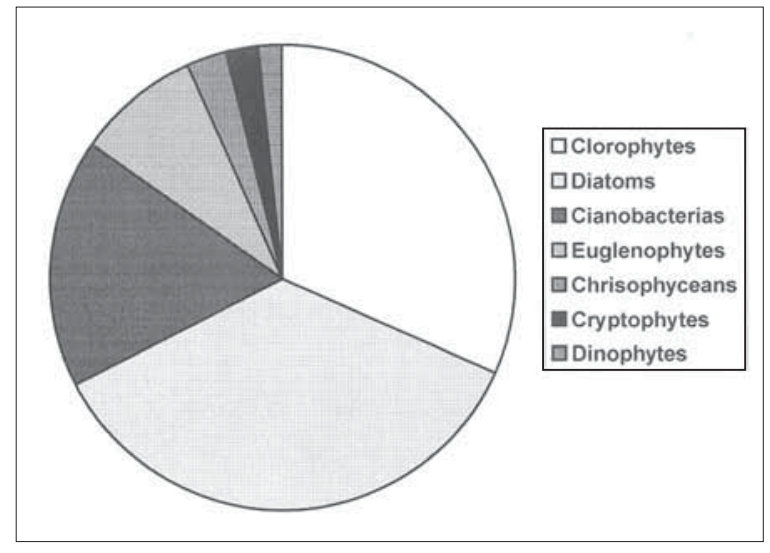

Figure 2. Phytoplankton composition in the study area. Composición florística del fitoplancton en la zona de estudio.

phytoplankton cells was observed with an inverted microscope following Utermöhl's method. Statistical analyses were performed with the software SPSS v12.0; community analyses (MDS, ANOSIM, PCA, SIMPER) with PRIMER v5. An analogue of the univariate ANOVA called ANOSIM was used to test for differences between multivariate samples from different sites or from different seasons (flooding vs. drying). A SIMPER test was used to identify the taxa primarily providing the discrimination between seasons. Similarity matrices of the multivariate samples were calculated using the Bray-Curtis coefficient after a $\log$-transformation $[\log (x+1)]$ of the original taxa abundances in order to perform a non-metric multidimensional scaling (MDS). The Shannon diversity index $\left(\mathrm{H}^{\prime}\right)$ was calculated as bits per cell using $\log _{e}$.

\section{RESULTS}

Phytoplankton composition included 224 taxa: 80 diatoms, 71 chlorophytes, 39 cyanobacteria, 19 euglenophytes, 6 chrysophytes, 5 cryptophytes, and 4 dinoflagellates (Fig. 2). Phytoplankton assemblages were very variable in both time and space as only 13 taxa had a frequency of appearance higher than $50 \%$, and just three species reached a frequency higher than $90 \%$ (Monoraphidium contortum, Cyclotella atomus and Nitzschia palea). Forty-two \% of taxa appeared
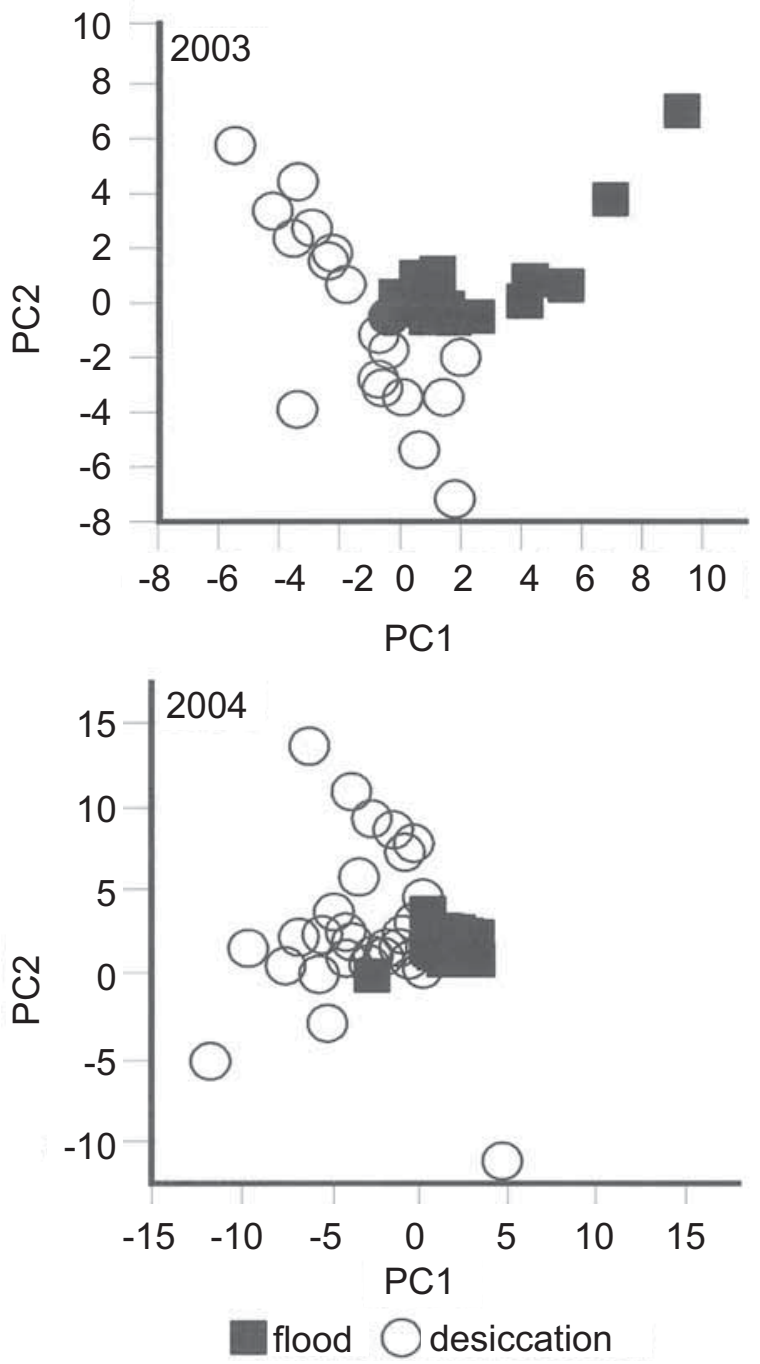

Figure 3. PCA ordination of phytoplankton assemblages at the different sampling sites grouped into flooding and desiccation periods for each hydrologic cycle. Ordenación PCA de la comunidad del fitoplancton en las distintas estaciones de muestro agrupadas en periodos de inundación y estiaje para cada ciclo hidrológico.

only during flooding, and $5 \%$ of taxa were restricted to dry times, whereas the majority of taxa appeared at any other season. Therefore a few taxa were widely distributed but no clear dominance was found. The diversity index $\left(\mathrm{H}^{\prime}\right)$ ranged from 0.37 to 2.93 in the whole of the study area, and from 0.51 to 2.84 at the inlet sites. Minimum diversity coincided with the occasional bloom of Chrysidalis sp.1 within the study area during June 2003 and at the inlet sites 
in June 2004 that reached $93 \%$ and $96 \%$ of relative abundance, respectively.

No spatial distribution of phytoplankton was observed according to the MDS ordination. In contrast, the PCA ordination of phytoplankton assemblages showed a temporal pattern where composition and abundance were seasonally segregated within each cycle (Fig. 3). The PCA analysis showed that $23.4 \%$ and $21.3 \%$ of the variation were explained by the first two axes in both the 2002/2003 and the 2003/2004 cycles, respectively. Phytoplankton assemblages during flooding were primarily arranged along the first PCA axis, while assemblages during dry periods were more sparsely distributed along the second PCA axis. An ANOSIM test was used to test whether phytoplankton assemblages were significantly segregated during floo- ding and dry periods. No clear segregation was found for the whole study area during either the $2002 / 03$ or the $2003 / 04$ cycles $(R=0.48$ and $R=0.61, p<0.01$, respectively). The inlet sites, however, were significantly segregated into two seasons during each cycle $(R=0.99$ and $R=0.87, p<0.01$, respectively). Few taxa contributed more than $5 \%$ to this segregation according to a SIMPER test, and only some of them accounted for the similarity of phytoplankton assemblages within certain periods: a) Chroococcus aff. minutus and Synechocystis sp. for 2002/03 flooding ; b) Tetradesmus aff. crocini for 2003/04 flooding; c) Limnothrix aff. planctonica for the 2003 dry period; and d) Merismopedia warmingiana, Chlorococcum sp. and Chroococcus dispersus for the 2004 dry period. The rest of the contributing species appeared

Table 1. Maximum abundance (cells/ml) of the main phytoplankton taxa in the study area during each cycle in the flooding and dissecation periods. Abundancias máximas (células/ml) de los principales taxa fitoplanctónicos en la zona de estudio durante cada ciclo en la época de inundación y de estiaje.

\begin{tabular}{|c|c|c|c|c|}
\hline & \multicolumn{2}{|c|}{ Cicle 2002/03 } & \multicolumn{2}{|c|}{ Cicle 2003/04 } \\
\hline & Flood & Dessication & Flood & Dessication \\
\hline Chroococcus aff. minutus & $8.1 \cdot 10^{3}$ & $9.3 \cdot 10^{3}$ & $10^{3}$ & $10^{3}$ \\
\hline Oscillatoria aff. planctonica & - & $1.3 \cdot 10^{4}$ & - & - \\
\hline Synechocystis sp. & $3.9 \cdot 10^{3}$ & - & $10^{2}$ & $6.1 \cdot 10^{4}$ \\
\hline Chlamydomonas sp. 3 & $1.6 \cdot 10^{3}$ & $0.1 \cdot 10^{3}$ & $4.1 \cdot 10^{3}$ & $10^{3}$ \\
\hline Chlamydomonas sp. 4 & - & $3.1 \cdot 10^{4}$ & $0.5 \cdot 10^{3}$ & $2.2 \cdot 10^{3}$ \\
\hline Chlorella vulgaris & $2.5 \cdot 10^{3}$ & $10^{3}$ & $0.3 \cdot 10^{3}$ & $10^{3}$ \\
\hline Coelastrum microporum & $3.8 \cdot 10^{4}$ & $3.7 \cdot 10^{3}$ & $3.9 \cdot 10^{3}$ & - \\
\hline Monoraphidium circinale & $3 \cdot 10^{3}$ & $2.4 \cdot 10^{3}$ & $0.2 \cdot 10^{3}$ & $0.4 \cdot 10^{3}$ \\
\hline Monoraphidium contortum & $1.9 \cdot 10^{4}$ & $1.4 \cdot 10^{4}$ & $2.4 \cdot 10^{4}$ & $7.2 \cdot 10^{4}$ \\
\hline Monoraphidium sp. & $5.1 \cdot 10^{3}$ & $10^{3}$ & $3.6 \cdot 10^{3}$ & $1.7 \cdot 10^{3}$ \\
\hline Pyramimonas sp. & - & - & $8.2 \cdot 10^{3}$ & $0.3 \cdot 10^{3}$ \\
\hline Scenedesmus ecornis & $2.1 \cdot 10^{3}$ & $10^{3}$ & $0.2 \cdot 10^{3}$ & $1.4 \cdot 10^{3}$ \\
\hline Schroederia sp. & $2.1 \cdot 10^{3}$ & $2.8 \cdot 10^{4}$ & $10^{3}$ & $1.8 \cdot 10^{3}$ \\
\hline Tetradesmus aff. crocini & $4.8 \cdot 10^{4}$ & - & $8.3 \cdot 10^{4}$ & - \\
\hline Cyclotella atomus & $7.6 \cdot 10^{3}$ & $7.6 \cdot 10^{3}$ & $2.1 \cdot 10^{4}$ & $2.6 \cdot 10^{4}$ \\
\hline Nitzschia acicularis & $0.8 \cdot 10^{3}$ & $1.2 \cdot 10^{4}$ & $0.2 \cdot 10^{3}$ & $1.2 \cdot 10^{4}$ \\
\hline Nitzschia longissima & $0.4 \cdot 10^{3}$ & $1.7 \cdot 10^{4}$ & $10^{4}$ & $0.4 \cdot 10^{3}$ \\
\hline Nitzschia palea & $6.1 \cdot 10^{3}$ & $2.8 \cdot 10^{4}$ & $1.5 \cdot 10^{4}$ & $3.2 \cdot 10^{4}$ \\
\hline Chrysidalis sp.1 & - & $8.3 \cdot 10^{5}$ & - & $2.6 \cdot 10^{5}$ \\
\hline Gymnodinium sp. & $3.6 \cdot 10^{3}$ & $5.6 \cdot 10^{3}$ & $0.6 \cdot 10^{3}$ & $0.6 \cdot 10^{3}$ \\
\hline
\end{tabular}



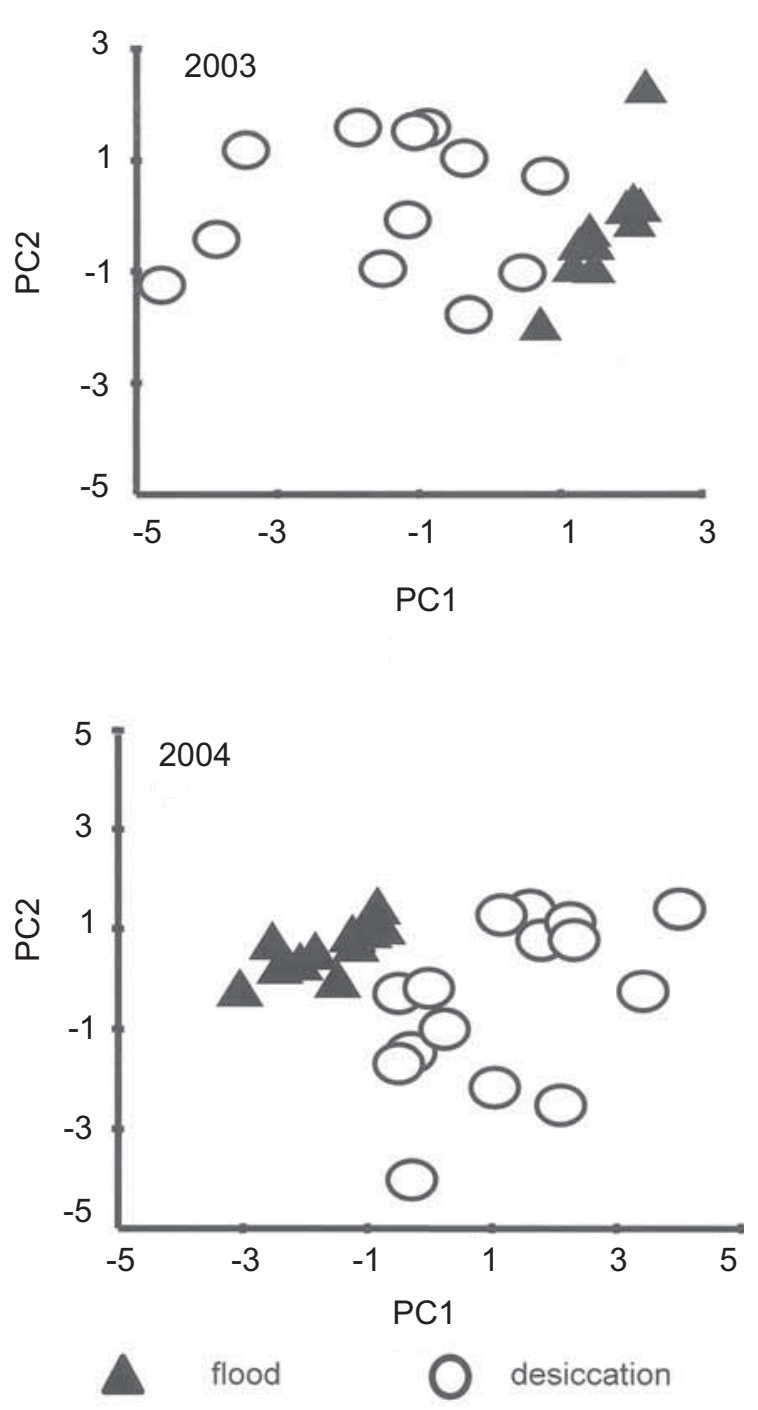

Figure 4. PCA ordination of physico-chemical variables at the different sampling sites grouped into flooding and desiccation periods for each hydrologic cycle. Ordenación PCA de las variables físico-químicas en las distintas estaciones de muestreo agrupadas en períodos de inundación y estiaje para ambos ciclos hidrológicos.

throughout the study period and only showed changes in abundance, such as $M$. contortum, N. palea, and C. atomus.

Abundance of the main phytoplankton taxa ranged widely within each period (Table 1). Some taxa reached maximum abundance during the dry periods (e.g., Schroederia sp., N. acicularis, N. palea, y Limnothrix aff. planctónica), while others were either more abundant du-

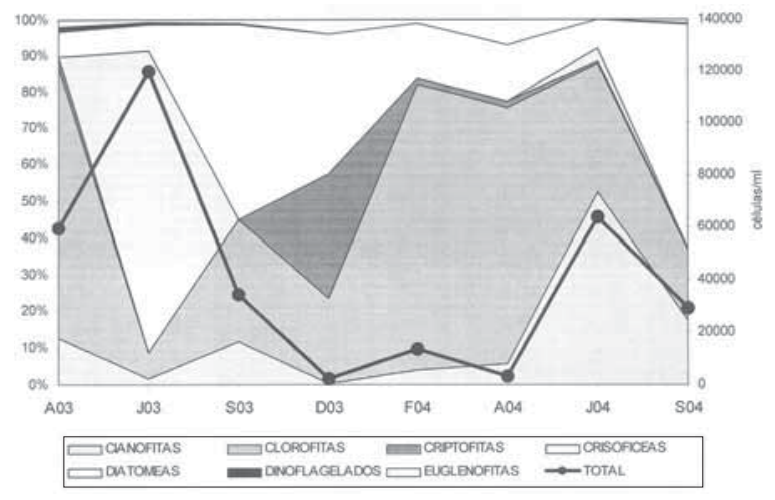

Figure 5. Evolution over the study period of the average abundance of main phytoplankton taxonomic groups (\%) and average total abundance (cells/ml) at all the inlet sites. Evolución a lo largo del período de estudio de la abundancia media de los principales grupos taxonómicos del fitoplancton (\%) y abundancia media total (cells $/ \mathrm{ml}$ ) en el conjunto de los puntos de "entrada".

ring flooding (Chlamydomonas sp. 3 y Coelastrum microporum) or maintained a relatively high abundance $\left(1.4 \cdot 10^{4}\right.$ cells $\left./ \mathrm{ml}\right)$ during all seasons (Monoraphidium contortum). On some occasions large abundances were preceded and/or followed by negligible abundances (Table 1) suggesting that episodes of colonization took place (e.g., Coelastrum microporum, Tetradesmus aff. crocini, Pyramimonas sp. and Chrysidalis sp. 1).

The concentrations of total $\mathrm{P}$ and suspended matter were generally high and reached up to $974.7 \mu \mathrm{g} / \mathrm{l}$ and $529.8 \mathrm{mg} / \mathrm{l}$, respectively, while $\mathrm{N}-\mathrm{NO}_{3}^{-}$concentration ranged from negligible values to $7.1 \mathrm{mg} / \mathrm{l}$. Suspended matter was largely inorganic as phytoplankton contributed with only $30 \%$ of the total. Planktonic chlorophyll $a$ ranged from $2.0 \mu \mathrm{g} / \mathrm{l}$ (February 2003) to $479.5 \mu \mathrm{g} / \mathrm{l}$ (September 2003), and was positively correlated with cell abundance $(r=0.59, p<0.001)$.

Some of these variables were cross-correlated with other, such as chlorophyll and conductivity $(r=0.53, p<0.01)$. Electrical conductivity was higher in summer; June rather than September attained the highest values at the inlet sites because of the dilution effect of freshwater draining from rice pads at the end of the cultivation season (September-October).

Environmental variables showed a seasonal segregation within each cycle (Fig. 4). The first 
Table 2. Number of samplings, number of stations, total samples $(n)$, surface of the study area $\left(\mathrm{km}^{2}\right)$, and total cumulative richness of phytoplankton in several coastal systems studied by different authors. Número de muestreos, número de estaciones muestreadas, total de muestras (n), superficie del área estudiada $\left(\mathrm{km}^{2}\right)$ y riqueza total acumulada del fitoplancton en diversas sistemas costeros estudiados por diferentes autores.

\begin{tabular}{|c|c|c|c|c|c|c|c|}
\hline Sites & System & Author & $\begin{array}{l}\text { Number of } \\
\text { samplings }\end{array}$ & $\begin{array}{l}\text { Samplings } \\
\text { sites }\end{array}$ & $n$ & Área & $\begin{array}{c}\text { Total richness } \\
\text { of phytoplankton }\end{array}$ \\
\hline & $\begin{array}{l}\text { Lucio Cangrejo Grande } \\
\text { (Doñana) }\end{array}$ & En este estudio & 11 & 30 & 146 & 2.4 & 224 \\
\hline 1 & $\begin{array}{l}\text { Guadiamar (Entremuros, } \\
\text { Doñana) }\end{array}$ & Toja et al., sin publicar & 18 & 3 & 43 & 5 & 89 \\
\hline \multirow[t]{3}{*}{5} & Estuario Guadalquivir & López, 1987 & 27 & 10 & 270 & 50 & 259 \\
\hline & $\begin{array}{l}\text { Lagunas Santa Olalla y Dulce } \\
\text { (R. B. Doñana) }\end{array}$ & Lopez et al., 1991 & 26 & 6 & 132 & 0.6 & 117 \\
\hline & Laguna de Tarelo (Doñana) & Serrano et al., 2004 & 20 & 2 & 40 & 0.16 & 55 \\
\hline 4 & Albufera Adra & Sánchez Castillo, 1987 & 13 & 3 & 39 & $>0.4$ & 58 \\
\hline \multirow[t]{2}{*}{6} & Albufera Valencia & Romo \& Miracle, 1995 & 114 & 3 & 342 & 21 & 131 \\
\hline & Albufera de Mallorca & Puigservé et al., 2002 & 20 & 4 & 105 & 0.7 & 74 \\
\hline 2 & La Safor & Rodrigo et al., 2003 & 2 & 32 & $<64$ & 13 & 128 \\
\hline 3 & Delta del Ebro & Sabater \& Muñoz, 1990 & 12 & 4 & 48 & - & 127 \\
\hline
\end{tabular}

two axis of a PCA ordination grouped $67.3 \%$ and $68.3 \%$ for 2002/03 and 2003/04, respectively. The variability accumulated by the first PCA axis was associated to dry conditions, and was correlated to the concentration of total $\mathrm{P}$, suspended matter, planktonic chlorophyll $a$, and conductivity. Flooding was associated to the second PCA axis, $\mathrm{pH}$ and nitrate concentrations being positively correlated, and ammonium and nitrite negatively correlated to this axis.

The relative abundance of phytoplankton taxa (\%) also followed a seasonal pattern at the inlet sites (Fig. 5). Chlorophytes dominated from the end of winter until the beginning of summer when chrysophytes became the dominant ones, though they were rapidly overturned by diatoms that dominated through autumn and winter. Small diatoms, such as $C$. atomus, were dominant until they were replaced by chlorophytes near the end of winter.

Cumulative phytoplankton richness was significantly correlated with the number of samplings $(r=0.77, p<0.05)$. The number of samplings was constrained by the availability of water at each site during the study. Therefore, the inlet sites, being permanent, accumulated the highest richness. Our study site ("Lucio El Cangrejo
Grande") showed a relatively high cumulative richness compared to other coastal wetlands with Mediterranean climate (Table 2). Both the number of samplings and the surface area were taken into account in order to compare our results. Sites 1, 2 and 3 accumulated a higher richness with a lower number of samplings. The study site had a similar richness than other sites of similar surface area (site 4) but higher richness per ha than nearby sites (sites 5 and 6 ).

\section{DISCUSSION}

Phytoplankton of coastal wetlands is generally composed of cosmopolitan species able to cope with wide variations in salinity, turbidity, and eutrophy. In areas dominated by a Mediterranean climate, this variability is often arranged in flooding and drying periods according to water availability. Therefore, the functioning of this kind of system is generally driven by factors related to seasonality and hydrology (Martín \& Comín, 1992; Comín et al., 1999). The hydrology of the study site is rather complex with both natural and artificial water bodies receiving water inputs from different origins depending on the 
season. Different water inputs would allow for the colonization of organisms from different origins (Comín et al., 1999). For this reason, hydrology is expected to play an important role in the composition of phytoplankton assemblages in the study area, particularly at the inlet sites, where larger exchanges are likely to occur. Similarly, Romo (1997) found that the phytoplankton composition of inlet channels draining the rice paddies was different from the composition at the inner sites of the Albufera of Valencia. In the present study, the composition and abundance of phytoplankton assemblages at the inlet sites were segregated seasonally, rather than spatially, into a flooding and a drying period. Similarly, the influence of temporal rather than spatial variability was more relevant for the composition of phytoplankton in the Albufera of Valencia (Romo \& Van Torengen, 1995). During dry periods, phytoplankton assemblages were more heterogeneous than during flooding, probably due to the combination of tidal rhythms and evaporation in isolated water bodies. This isolation was larger in 2002/03 when the floodgate remained closed during both the flooding and dry seasons, while in the following cycle it was open from the end of June till mid October 2004.

The main phytoplankton taxa involved in this segregation belonged to cyanobacteria, diatoms, chlorophytes, and crysophytes. Chlorophytes and diatoms have been reported to reach a large abundance in coastal wetlands fringing rice paddies in the Ebro Delta (Forés \& Comín, 1992). Cyanobacteria are common in marshes during the summer (Martín \& Comín, 1992; Quintana \& Moreno-Amich, 2002; López- Flores et al., 2006). In the estuary of the Guadalquivir River, cyanobacteria dominated in spring-summer with species belonging to the genera: Limnothrix, Chroococcus and Merismopedia (López, 1987). In the present study, $L$. aff. planctonica, $C$. dispersus and $M$. warmingiana were more abundant during dry periods at the inlet sites. The chlorococcal chlorophyte Tetradesmus aff. crocini was, in contrast, more abundant during flooding periods. It is likely that the intermittent appearance of this taxon was due to episodes of colonization as this species has been recorded in the vi- cinity, both in the estuary of the Guadalquivir River (López, 1987) and in the Guadiamar River (Marín \& García-Novo, 2006). Another taxon likely involved in colonization episodes was Chrysidalis $\mathrm{sp}$. 1, but this taxon has not been recorded earlier in nearby areas. Chrysophiceans are a significant fraction of marine phytoplankton and can also reach high abundance in brackish, Mediterranean wetlands (Sorokin et al., 1996; CruzPizarro et al., 2003; Rodrigo et al., 2001). The intermittent appearance of this taxon during June 2003 and 2004 contributed to the seasonal segregation of phytoplankton assemblages in flooding and drying periods. The concentration effect of evaporation could explain its high abundance during summer, which was 4 times higher than the most abundant taxon recorded in the estuary of the Guadalquivir River (López, 1987). In fact, phytoplankton abundance and chlorophyll concentration were always higher during the dry periods at all sites, while dilution effects dominated during flooding periods. This seasonal pattern explains the cross-correlation between chlorophyll concentration and electrical conductivity. Although $\mathrm{P}$ concentration was associated to dry periods and nitrate to flooding periods, nutrient concentrations were high enough to ensure primary production all year long. Total $\mathrm{P}$ concentration was higher during dry periods because both algal biomass and suspended matter were higher in the summer, inorganic suspended matter and total $\mathrm{P}$ being positively correlated at the inlet sites (Serrano et al., 2006). Nitrate was higher during flooding because of drainage and runoff of agricultural soils in the Guadiamar River watershed (Cabrera et al., 1984). Consequently, the most abundant taxa in the study period corresponded to the functional groups of Reynold's (2002) classification D, J and X1 which are indicative of shallow systems rich in nutrients.

The positive correlation between cumulative phytoplankton richness and number of samplings $(r=0.77, p<0.05)$ indicate that a longer study period and/or a higher frequency of samplings are required to record the total number of taxa at the study area. Few taxa had a wide distribution within the study area. Only $M$. contortum, $C$. atomus and $N$. palea had a 
frequency of appearance higher than $90 \%$. They are species typical of estuaries (López, 1987; Trigueros \& Orive, 2000 and 2001), able to cope with rapid environment changes due to their short reproduction time (Krienitz et al., 1997 in Negro et al., 2000).

In conclusion, phytoplankton cumulative richness was high in relation to other coastal wetlands under mediterranean climate despite that the study site receives a higher input of nutrients compared to the southern Doñana marshland (Espinar et al., 2002). The study area was featured as a fluctuating environment influenced by colonization episodes due to its hydrologic heterogeneity and water input variability. A large part of this hydrologic variability is man-made and future modifications are planned according to the hydrologic regeneration plan for the Doñana marshland ("Doñana 2005").

\section{ACKNOWLEDGEMENTS}

We are very grateful to Pilar and Julio (from Huerta Tejada), to the rangers of Doñana Natural Park, and to our colleagues Gonzalo Martín, Aran Arechederra, Marta Reina, David León, Virgilio Hermoso, Paco Blanco, and Pepe Prenda. This work was partly funded by the Consejería de Medio Ambiente, Junta de Andalucía, Spain.

\section{REFERENCES}

ARAMBARRI, P., F. CABRERA y C. G. TOCA. 1984. La contaminación del río Guadiamar y su zona de influencia, Marismas del Guadalquivir y Coto Doñana, por residuos de industrias mineras y agrícolas. Talleres Gráficos. CSIC. Madrid. 174 pp.

ARAMBARRI, P., F. CABRERA \& R. GONZÁLEZ-QUESADA, 1996. Quality evolution of waters entering the Doñana National Park (SW, Spain). Sci. Total Environ., 191: 185-196.

CABRERA, F., C. G. TOCA, E. DÍAZ \& P. ARAMBARRI, 1984. Acid mine-water and agricultural pollution in a river skirting the Doñana National Park (Guadiamar River, South West Spain). Water Research, 18: 1469-1482.
CABRERA, F., R. CORDÓN \& P. ARAMBARRI, 1987. Metales pesados en las aguas y sedimentos de los estuarios de los ríos Guadalquivir y Barbate. Limnetica 3: 281-290.

COMÍN, A. \& I. VALIELA, 1993. On the Controls of phytoplankton abundance and production in coastal lagoons. Journal of Coastal Research, 9 (4): 895-906.

COMÍN, F. A., F. MENÉNDEZ, J. A. ROMERO, O. HERNÁNDEZ, M. MARTÍNEZ \& A. CHACÓN. 1999. Indicadores ecológicos y herramientas para la gestión de ecosistemas acuáticos en la zona costera. Limnetica, 16: 61-68.

CRUZ-PIZARRO, L., I. DE VICENTE, E. MORENO-OSTOS, V. AMORES y K. EL MABROUKI, 2003. Estudios de diagnósticos y viabilidad en el control de la eutrofización de las aguas de la Albufera de Adra. Limnetica, 22: 135-154.

DE GROOT, K. J. \& H. L. GOLTERMAN. 1990. Sequential fractionation of sediment phosphate. Hydrobiologia, 192: 143-149.

ESPINAR, J. L., L. V. GARCÍA, P. GARCÍA MURILLO, J. TOJA, 2002. Submerged macrophyte zonation in a mediterránean salt marsh: a facilitation effect from established helophytes? J. Veg. Sci., 13:813-840.

FORÉS, E. \& F.A. COMÍN, 1992. Ricefields, a limnological perpestive. Limnetica, 8: 101-109.

GILABERT, J. 2001. Seasonal plankton dynamics in a Mediterranean hypersaline coastal lagoon: the Mar Menor. J. Plankton Res., 23 (2): 207-217.

GOLTERMAN, H. L. 1991. Direct nesslerization of ammonia and nitrate in fresh-water. Annls. Limnol., 27: 99-101.

HLAILI A. S., M. A. CHIKHAOUI, B. EL GRAMI $\&$ H. H. MABROUK, 2006. Effects of $\mathrm{N}$ and $\mathrm{P}$ supply on phytoplankton in Bizerte Lagoon (western Mediterranean). Journal of Experimental Marine Biology and Ecology, 333 (1): 79-96.

LÓPEZ, T. 1987. Limnología del estuario del Guadalquivir. Incidencia de los factores del medio en la distribución y sucesión del fitoplancton. Tesis de Licenciatura. Universidad de Sevilla. 146 pp.

LÓPEZ, T., J. TOJA \& N. A. GABELLONE. 1991. Limnological comparison of two peridunar ponds in the Doñana National Park (Spain). Arch. Hydrobiol., 120: 357-378.

LÓPEZ-FLORES, R., D. BOIX, A. BADOSA, S. BRUCET \& X. D. QUINTANA, 2006. Pigment composition and size distribution of phytoplankton 
in a confined Mediterranean salt marsh ecosystem. Marine Biology, 149: 1313-1324.

MARTÍN, M. T. \& F. A. COMÍN, 1992. Plankton populations dynamics in a salt marsh used as clam nursey. In: Marine Eutrophication and population dynamics. Giuseppe Colombo et al. (eds.). Olsen \&Olsen Fredensborg, Demark.

MARÍN GARCÍA, C. \& F. GARCÍA NOVO. 2006. Doñana Water and Biosphere. Doñana 2005, Confederación Hidrográfica del Guadalquivir, Ministerio de Medio Ambiente, 353 pp.

MURPHY, J. \& J. P. RILEY. 1962. A modified single solution method for the determination of soluble phosphate in natural waters. Analitycal Chemical Acta, 27: 31-36.

MUYLAERT, K. \& R. RAINE, 1999. Import, mortality and accumulation of coastal phytoplankton in a partially mixed estuary (Kinsale harbour, Ireland). Hydrobiologia, 412:53-65

NEGRO, A. I., C. DE HOYOS \& J. C. VEGA, 2000. Phytoplankton structure and dinamics in lake Sanabria and Valparaiso reservoir (NW Spain). Hydrobiologia, 424: 25-37.

NUCCIO, C., C. MELILLO, L. MASSI \& M. INNAMORATI. 2003. Phytoplankton abundance, community structure and diversity in the eutrophicated Orbetello lagoon (Tuscany) from 1995 to 2001. Oceanologica Acta, 26: 15-25.

ODUM, W. E. 1988. Comparative ecology of tidal freshwater and salt marshes. Ann. Rev. Ecol. Syst., 19: 147-176.

ORTEGA-MAYAGOITIA E., C. ROJO \& M. A. RODRIGO, 2003. Controlling factors of phytoplankton assemblages in wetlands: an experimental approach. Hydrobiologia, 502 (1-3): 177-186.

POMEROY, L. R. 1977. Nutrients in Estuaries. In: Coastal Ecosystem Management. J. R. Clark (ed.), 673-677. J. Wiley \& Sons, N.Y.

PUIGSERVER, M., G. RAMON \& G. MOYA, 2002. Spatial and temporal distribution of phytoplankton a Mediterranean Estuarine Canal System. Journal of Coastal Research, 18, (1): 39-51.

QUINTANA, X. D. \& R. MORENO-AMICH, 2002. Phytoplankton composition of Empordá salt marshes and its response to freshwater flux regulation. J. Coastal Res., 36, 581-590.

REINA, M., ESPINAR, J. L. \& L. SERRANO. 2006. Sediment phosphate composition in relation to emergent macrophytes in the Doñana Marshes (SW Spain). Wat. Res., 40: 1185-1190.
REYNOLDS C. S., V. HUSZAR, C. KRUK, L. NASELLI-FLORES \& S. MELO. 2002. Towards a functional classification of the freshwater phytoplankton. J. Plankton Res., 24(5) 417-428.

RODIER, J. 1981. Análisis de aguas. Omega (ed.). Barcelona. 1059 pp.

RODRIGO M. A., X. ARMENGOL-DÍAZ, R. OLTRA, M. J. DASÍ \& W. COLOM, 2001. Environmental variables and planktonic communities in two ponds of El Hondo wetland (SE Spain). International Review of Hydrobiology, 86: 299-315.

RODRIGO M. A., C. ROJO \& X. ARMENGOL, 2003. Plankton biodiversity in a landscape of shallow water bodies. (Mediterranean coast, Spain). Hydrobiologia, 506-509: 317-326.

ROMO, S. 1997. Importance of allochthonous phytoplankton in a coastal freshwater lake. Verh. Internat. Verein. Limnol., 26: 610-614.

ROMO, S. \& M. R. MIRACLE, 1995. Diversitiy of the phytoplankton assemblages of a polymictic hypertrophic lake. Archiv für Hydrobiologie, 132: 363-384.

ROMO, S. \& O. VAN TORENGEN, 1995. Multivariantes análisis of phytoplancton and related enviromental factors, in a shallow hypertrophic lake. Hydrobiologia, 299: 93-101.

SABATER, S. \& I. MUÑOZ, 1990. Successional dynamics of the phytoplankton in the lower part of the river Ebro. J. Plankton Res., 12 (3): 573-592.

SÁNCHEZ-CASTILLO, P. M. 1987. Influencia de la salinidad sobre las poblaciones algales de tres lagunas litorales (Albufera de Adra, Almería). Limnetica, 3: 47-53.

SERRANO, L., M. REINA, A. ARECHEDERRA, M. A. CASCO \& J. TOJA. 2004. Limnological description of the Tarelo lagoon (SW Spain). Limnetica, 23: 1-10.

SERRANO, L., M. REINA, G. MARTÍN, I. REYES, A. ARECHEDERRA, D. LEÓN \& J. TOJA, 2006. The aquatic systems of Doñana (SW Spain): watersheds and frontiers. Limnetica, 25(1-2): 1132.

SILJESTRÖN, P. A. \& L. CLEMENTE. 1990. Geomorphology and soil evolution of a moving dune system in sourth-west, Spain (Doñana National Park). Journal of Arid Enviroments, 18: 139-150.

SOROKIN, Y. I., F. DALLOCCHIO, F. GELLI \& L. ANDA PREGNOLATO. 1996. Phosphorus metabolism in anthropogenically transformed lagoon ecosystems: The Comacchio lagoons (Ferrara, Italy). Journal of Sea Research, 35 (4): 243-250. 
STRICKLAND, J. D. \& T. R. PARSONS, 1972. A practical handbook of seawater analyses. Fish. Res. Bd. Can. Bull., 167 pp.

TRIGUEROS, J. M. \& E. ORIVE. 2000. Tidal driven distribution of phytoplankton bloom in a shallow macrotidal estuary. J. Plankton Res., 22: 969-986.

TRIGUEROS, J. M. \& E. ORIVE. 2001. Seasonal variations of diatoms and dinoflagellates in shallow, temperate estuary, with emphasis on neritic asseemblages. Hydrobiologia, 444: 119-133.
VILLENA, M. J. \& S. ROMO. 2003. Phytoplankton changes in a shallow Mediterranean lake (Albufera of Valencia, Spain) after sewage diversion. Hydrobiologia 506-509: 281-287.

ZURERA COSANO, G., F. RINCÓN LEÓN, L. M. POLO VILLAR, M. JODRAL VILLAREJO, R. JORDANO SALINAS \& R. POZO LORA. 1987. Contaminación por plomo, cadmio y mercurio en aguas y sedimentos del río Guadalquivir. Actas del IV Congreso Español de Limnología. Sevilla: 307-314. 